NASA/TM—2008-215169

\title{
Operability of an Ejector Enhanced Pulse Combustor in a Gas Turbine Environment
}

Daniel E. Paxson

Glenn Research Center, Cleveland, Ohio

Kevin Dougherty

ASRC Aerospace, Cleveland, Ohio 


\section{NASA STI Program . . . in Profile}

Since its founding, NASA has been dedicated to the advancement of aeronautics and space science. The NASA Scientific and Technical Information (STI) program plays a key part in helping NASA maintain this important role.

The NASA STI Program operates under the auspices of the Agency Chief Information Officer. It collects, organizes, provides for archiving, and disseminates NASA's STI. The NASA STI program provides access to the NASA Aeronautics and Space Database and its public interface, the NASA Technical Reports Server, thus providing one of the largest collections of aeronautical and space science STI in the world. Results are published in both non-NASA channels and by NASA in the NASA STI Report Series, which includes the following report types:

- TECHNICAL PUBLICATION. Reports of completed research or a major significant phase of research that present the results of NASA programs and include extensive data or theoretical analysis. Includes compilations of significant scientific and technical data and information deemed to be of continuing reference value. NASA counterpart of peer-reviewed formal professional papers but has less stringent limitations on manuscript length and extent of graphic presentations.

- TECHNICAL MEMORANDUM. Scientific and technical findings that are preliminary or of specialized interest, e.g., quick release reports, working papers, and bibliographies that contain minimal annotation. Does not contain extensive analysis.

- CONTRACTOR REPORT. Scientific and technical findings by NASA-sponsored contractors and grantees.

- CONFERENCE PUBLICATION. Collected papers from scientific and technical conferences, symposia, seminars, or other meetings sponsored or cosponsored by NASA.

- SPECIAL PUBLICATION. Scientific, technical, or historical information from NASA programs, projects, and missions, often concerned with subjects having substantial public interest.

- TECHNICAL TRANSLATION. Englishlanguage translations of foreign scientific and technical material pertinent to NASA's mission.

Specialized services also include creating custom thesauri, building customized databases, organizing and publishing research results.

For more information about the NASA STI program, see the following:

- Access the NASA STI program home page at http://www.sti.nasa.gov

- E-mail your question via the Internet to help@ sti.nasa.gov

- Fax your question to the NASA STI Help Desk at 301-621-0134

- Telephone the NASA STI Help Desk at 301-621-0390

- Write to: NASA Center for AeroSpace Information (CASI) 7115 Standard Drive Hanover, MD 21076-1320 
NASA/TM—2008-215169

\section{Operability of an Ejector Enhanced Pulse Combustor in a Gas Turbine Environment}

Daniel E. Paxson

Glenn Research Center, Cleveland, Ohio

Kevin Dougherty

ASRC Aerospace, Cleveland, Ohio

Prepared for the

46th Aerospace Sciences Meeting and Exhibit

sponsored by the American Institute of Aeronautics and Astronautics

Reno, Nevada, January 7-10, 2008

National Aeronautics and

Space Administration

Glenn Research Center

Cleveland, Ohio 44135 


\section{Acknowledgments}

We are grateful to many individuals for their dedicated contributions to designing, installing, and operating this experiment. However, the efforts of our mechanic, Robert Pelaez, and electrical technician, Mark Robinson deserve special mention. Their abilities in completing ill-described tasks (typically scribbled on pieces of paper), on a small budget, and through countless unforeseen difficulties, represent the best of the NASA Glenn Facility Support staff. We are also grateful to the Controls and

Dynamics Branch Chief, Sanjay Garg for his support of this research despite a period of very lean resource allocations.

This report is a formal draft or working paper, intended to solicit comments and ideas from a technical peer group.

This report contains preliminary findings, subject to revision as analysis proceeds.

This work was sponsored by the Fundamental Aeronautics Program at the NASA Glenn Research Center.

Level of Review: This material has been technically reviewed by technical management.

Available from

NASA Center for Aerospace Information 7115 Standard Drive Hanover, MD 21076-1320
National Technical Information Service 5285 Port Royal Road Springfield, VA 22161 


\title{
Operability of an Ejector Enhanced Pulse Combustor in a Gas Turbine Environment
}

\author{
Daniel E. Paxson \\ National Aeronautics and Space Administration \\ Glenn Research Center \\ Cleveland, Ohio 44135 \\ Kevin Dougherty \\ ASRC Aerospace \\ Cleveland, Ohio 44135
}

\begin{abstract}
A pressure-gain combustor comprised of a mechanically valved, liquid fueled pulsejet, an ejector, and an enclosing shroud, was coupled to a small automotive turbocharger to form a self-aspirating, thrust producing gas turbine engine. The system was constructed in order to investigate issues associated with the interaction of pulsed combustion devices and turbomachinery. Installed instrumentation allowed for sensing of distributed low frequency pressure and temperature, high frequency pressure in the shroud, fuel flow rate, rotational speed, thrust, and laboratory noise. The engine ran successfully and reliably, achieving a sustained thrust of 5 to $6 \mathrm{lbf}$, and maintaining a rotor speed of approximately 90,000 rpm, with a combustor pressure gain of approximately 4 percent. Numerical simulations of the system without pressure-gain combustion indicated that the turbocharger would not operate. Thus, the new combustor represented a substantial improvement in system performance. Acoustic measurements in the shroud and laboratory indicated turbine stage sound pressure level attenuation of $20 \mathrm{~dB}$. This is consistent with published results from detonative combustion experiments. As expected, the mechanical reed valves suffered considerable damage under the higher pressure and thermal loading characteristics of this system. This result underscores the need for development of more robust valve systems for this application. The efficiency of the turbomachinery components did not appear to be significantly affected by unsteadiness associated with pulsed combustion, though the steady component efficiencies were already low, and thus not expected to be particularly sensitive.
\end{abstract}

\section{Nomenclature}

$\begin{array}{ll}\text { A } & \text { area } \\ C_{d} & \text { discharge coefficient } \\ \Delta \mathrm{P} & P_{\text {Tin }}-P_{\text {Cout }} \\ F & \text { thrust force } \\ g_{c} & \text { Newton constant, } 32.174 \mathrm{lbm} \mathrm{ft} / \mathrm{lbf} \mathrm{s}^{2} \\ \gamma & \text { ratio of specific heats } \\ \dot{m} & \text { mass flow rate, lbm } / \mathrm{s} \\ \mathrm{N} & \text { rotational speed, rpm } \\ N_{c} & \text { corrected rotor rotational speed, } N / \sqrt{T_{t} / T_{\text {tref }}}, \mathrm{rpm} \\ P & \text { total pressure, psia } \\ p & \text { static pressure, psia } \\ P R_{T} & \text { turbine total pressure ratio, } P_{\text {Tin }} / p_{\text {Tout }} \\ P R_{C} & \text { compressor total pressure ratio, } P_{\text {Cout }} / P_{\text {Cin }} \\ \mathrm{rms} & \text { root mean square } \\ S P L & \text { sound pressure level }\end{array}$




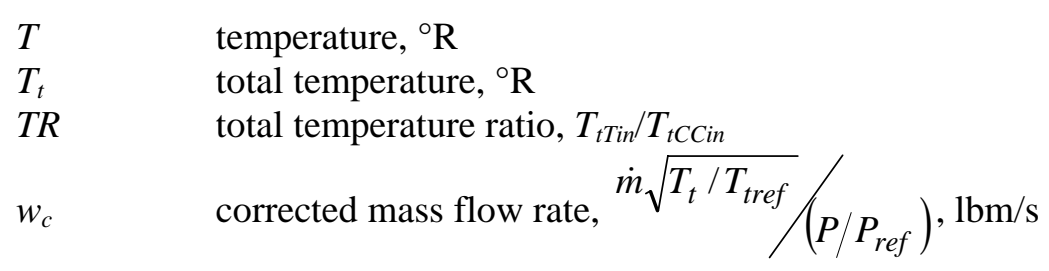

\section{Subscripts}

$\begin{array}{ll}\text { amb } & \text { ambient } \\ C & \text { compressor } \\ \text { CC } & \text { combustion Chamber } \\ \text { in } & \text { Inlet station } \\ \text { out } & \text { outlet station } \\ \text { pj } & \text { pulsejet } \\ \text { ref } & \text { reference } \\ T & \text { turbine }\end{array}$

\section{Introduction}

Conventional gas turbine combustors suffer a loss in total pressure as they heat the working fluid. The loss arises from heating at finite Mach number, and from aerodynamic losses associated with the flow path (e.g., liner cooling, mixing requirements, etc.). Typical combustor losses range from 4 to 8 percent of the total pressure delivered from the upstream compressor (ref. 1). The loss in total pressure yields lower work potential for the gas entering the downstream turbine. The resulting performance loss to the engine in terms of reduced specific thrust and/or increased specific fuel consumption can be significant. It has been shown that if instead, a pressure rise of 3 percent could be achieved across the combustor, improvements (reductions) in specific fuel consumption of 2 to 3 percent are theoretically possible (ref. 2).

The recognized benefits of pressure-gain combustion have been the impetus for several investigations both in decades past (refs. 3 to 6) and in the near present (refs. 7 and 8). Most have shown the pressuregain combustor to be competitive with many concepts for improving gas turbine performance (e.g., flow control, advanced materials, etc.). In every investigation, pressure-gain is achieved through some approximation of the constant-volume combustion process. As a result, every concept relies on some form of intermittent combustion. This, in turn, yields a combustor exit flow that is unsteady to one degree or another. Since unsteadiness is generally regarded as a detriment to the performance of downstream turbomachinery, its presence tends to detract from the thermodynamic benefits of the pressure gain. Therefore it is desirable in any intermittent combustion process to minimize unsteadiness in the exhaust path. Furthermore, the pulsed combustor effluent is generally at temperatures far too high to be sent directly into a turbine. Some form of bypass and mixing is necessary. This also reduces pressure rise, and must therefore be managed carefully.

In 2005 an ejector enhanced, pulsed, pressure-gain combustor experiment was fabricated and tested at the NASA Glenn Research Center (GRC) (ref. 2). The unit consisted of a commercial, liquid fueled, valved pulsejet, and an optimized ejector, housed within a shroud. The combination formed an effective combustor across which there was shown a modest 3 to 4 percent total pressure gain associated with a temperature ratio of approximately 2.3. This temperature ratio is typical for many gas turbine engines. The system demonstrated unsteady rms total pressure levels measuring 4 to 5 percent of the mean. The rig was operated at pressures up to 2 atmospheres using a facility shop air supply. However, no provisions were made to heat the inlet air to temperatures appropriate to a compressor exit. It is believed that the temperature of the inlet air affects operability of resonant combustors because it alters the speed of sound. 
Furthermore, the combustor exhaust was simply vented to the ambient atmosphere, so the impact of the pressure rise and unsteadiness on downstream turbomachinery could not be assessed.

This paper represents a preliminary effort to address these, and other issues. The combustor experiment has been modified by the addition of a small automotive turbocharger sized for the combustor air flow rate. Air from the turbocharger compressor discharge now supplies the combustor, and the combustor discharge is now directed through the turbocharger turbine. The combined components form a free-running, thrust producing gas turbine engine. The experiment is sufficiently instrumented such that performance may be assessed, including the impact of unsteadiness on turbine operation, the attenuation of combustion noise by the turbine, and the impact of surrounding turbomachinery on pulsed combustor operation. The experimental setup will be described, and operational issues will be discussed. Results will then be presented, along with associated analyses based on comparison with a simple, four-state, dynamic engine simulation. The paper will conclude with a summary of significant findings and suggestions for further research.

\section{Experimental Apparatus Description}

The experimental setup is shown schematically figure 1. Instrumentation locations are also shown, along with numbered measurement station designations. A photograph of the assembled rig is presented in the appendix, as figure 12. Total pressures are measured using pitot-probes. Low frequency pressure transducers are remotely located and connected to the probes using long (at least $4 \mathrm{ft}$ ), $0.63 \mathrm{in}$. outside diameter tubing. The long tubing effectively eliminates pressure fluctuations above $10 \mathrm{~Hz}$ at the transducers. Total temperatures are measured using open-weld, Type-K thermocouples (weld diameter $<0.03 \mathrm{in}$.) located at the tips of 0.063 in. diameter probes. A functional, verbal description of the experiment follows.

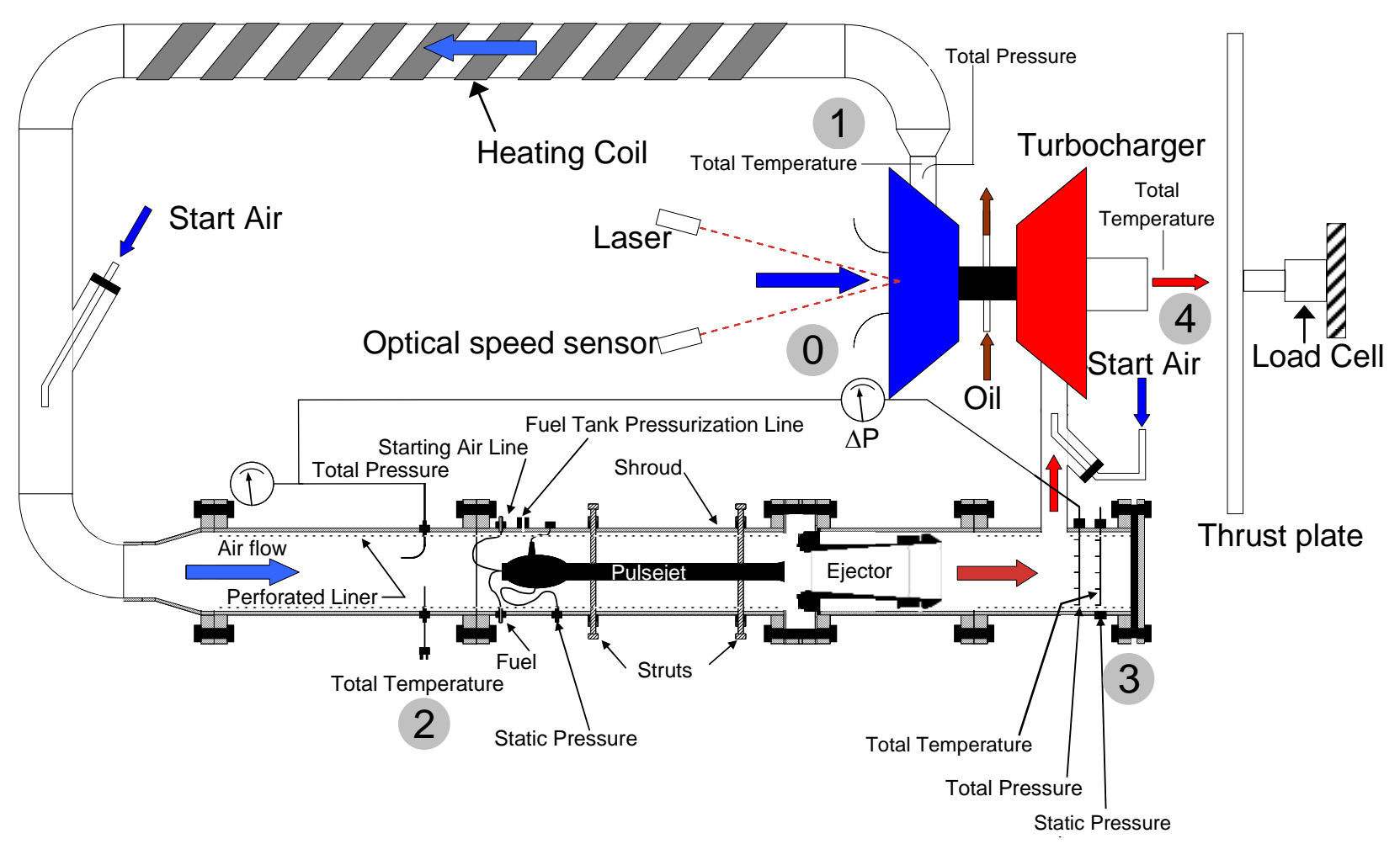

Figure 1.-Schematic diagram of the experiment showing components, instrumentation, and measurement stations. 
The turbocharger is a Holset HX35W model, used primarily in diesel pickup trucks. Air enters the centrifugal compressor through a bellmouth inlet, and is discharged through a 2.0 in. diameter pipe. A short diffuser provides transition to a 4.0 in. diameter pipe, which carries the compressed air to the combustor inlet. The Mach number at the compressor exit is generally below 0.15 , therefore the short diffuser is expected to produce pressure losses of less than 1.0 percent of the total available. Test run times in the experiment are limited to approximately $15 \mathrm{sec}$ (ref. 9), which is not enough time for the large thermal mass of the pipe leading to the combustor inlet to reach equilibrium. This means that the pipe substantially cools the transported compressor discharge air. Preliminary tests showed a drop of nearly $75^{\circ} \mathrm{R}$ during a typical run. In order to reduce the drop, the pipe is wrapped with a heating strip, which is activated hours before any testing commences. Upon entering the combustor section, the air flow is split. A portion passes through the pulsejet, mixes with the gasoline fuel, and participates in the semiconstant volume reaction associated with resonant combustion. The remaining air bypasses the pulsejet and mixes with the pulsejet effluent in the ejector. The mass flow split cannot be actively controlled, nor can the venturi-based fuel supply to the pulsejet used in this experiment. As such, there is only one operating point for the system. The heated, mixed, and pressurized air is next sent to the turbine via a 2.0 in. diameter pipe branching from the aft end of the 6.0 in. diameter combustor. Total pressure losses from this branch are also expected to be small as the Mach number is low (approximately 0.17 in the 2.0 in. diameter section), the flow is accelerating, and the edges of the branch have been rounded (ref. 10). After passing through the radial turbine, the flow exits the rig and impinges on a 36.0 in. diameter thrust plate which is in contact with load cell to provide thrust measurement (ref. 9). Rotor speed is measured by a remote optical sensor located upstream of the compressor and wired to a pulse-counting tachometer. The sensed light pulse is provided by a laser beam reflecting from the smooth metal surface of a $0.1 \mathrm{in}$. diameter exposed portion of the compressor retaining nut which is otherwise painted with a flat gray finish. The arrangement is shown in figure 2. Starting air for the system is provided by the two 0.5 in. diameter jets shown in figure 1. Flow through the jets is near sonic and serves not only to provide air, but to induce flow in the desired direction (i.e., to impart streamwise momentum as does a steady ejector). A separate air flow line is provided for starting of the pulsejet, as described in reference 9. A $60 \mathrm{~Hz}$. spark system is also provided for pulsejet starting. Neither start air nor sparking are required once resonant operation is established. Lubrication of the turbocharger is provided by an oil distribution system driven by a sump-fed, electric pump. Fuel flow is measured using a low-loss turbine-type meter.

A description of the pulsejet which drives the pressure-gain combustor is not included in this paper. Physical and operational details may be found in references 2 and 9. Briefly however, it is a commercial design intended for use in propelling model aircraft. It uses liquid fuel (gasoline), normally operates in

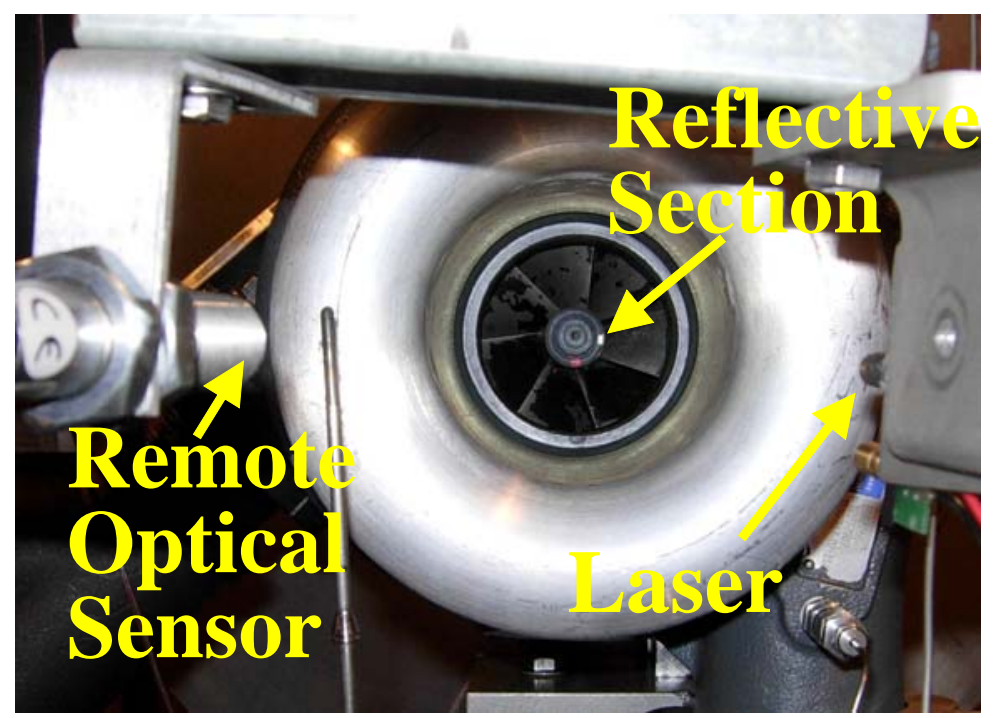

Figure 2.-Turbocharger speed sensing apparatus. 
atmospheric conditions at a frequency of approximately $220 \mathrm{~Hz}$, and develops approximately $4.2 \mathrm{lbf}$ thrust. The valve is a mechanical reed-type which is passively actuated by pressure differences that arise from the semi-constant volume combustion process and associated gasdynamic cycle occurring in the pulsejet combustion chamber and tailpipe.

A typical test run of the system proceeds as follows. Lubricating oil flow is established by activating the pump. Airflow is then established through the starting lines, and is increased until the turbocharger rotational speed is between 45,000 and 50,000 rpm. The fuel line is then opened. The sparking system is activated, and the pulsejet starting air is actuated in short bursts. Resonant combustion soon follows, along with a rapid increase in rotor speed and turbine inlet temperature. The spark system is then turned off, along with the pulsejet starting air. Immediately following this, the turbocharger starting air flow is gradually reduced to zero over an approximately 4 sec interval. Abruptly turning off this air causes the pulsed combustion to cease. From this time to the end of the test run, the system achieves a reasonably stable operating condition. After $15 \mathrm{sec}$ of pulsejet operation, the fuel supply line is closed, and the test run ends. Sensor data is acquired during the entire start and operation sequence at a sampling rate of $1 \mathrm{~Hz}$ using the PC-based facility system. Selected high frequency data is acquired using a digital storage oscilloscope sampling at $10.0 \mathrm{kHz}$ over a $1.0 \mathrm{sec}$ interval.

\section{A. Turbomachinery Characterization}

Before the complete experiment was operated, the individual turbomachinery components were tested under cold flow conditions in order to verify performance maps, or to establish maps that were unavailable. The first component tested was the turbine. The output duct of the compressor was disconnected from the duct leading to the combustor and was vented to the atmosphere across an orifice (to provide compressor loading). The starting air line nearest the turbine was closed, while that near the combustor inlet was significantly enlarged to provide more air flow. The duct upstream of the enlarged starting air line was blocked off. Metered air was thus fed through the turbine while the turbine inlet and exit conditions, as well as speed, were monitored. The results are shown in figure 3 . Here measured corrected mass flow rate is compared to the corrected mass flow rate predicted by the compressible orifice flow formula over a range of turbine pressure ratios. The formula, which has two forms for choked and unchoked flows, is written as follows.

$$
\begin{gathered}
\frac{\dot{m} \sqrt{\frac{T_{\text {tTin }}}{T_{\text {tref }}}}}{\left(\frac{P_{\text {Tin }}}{P_{\text {ref }}}\right)}=C_{d} A \sqrt{\frac{2 \gamma g_{c}}{(\gamma-1) R_{g} T_{\text {tTin }}}} P R_{T}\left(\frac{-1}{\gamma}\right)\left(1-P R_{T}^{\left.\left(\frac{1-\gamma}{\gamma}\right)\right)^{\frac{1}{2}}, P R_{T}<\left(\frac{\gamma+1}{2}\right)\left(\frac{\gamma}{\gamma-1}\right)}\right. \\
=C_{d} A \sqrt{\frac{2 \gamma g_{c}}{(\gamma-1) R_{g} T_{\text {tTin }}}}\left(\frac{\gamma+1}{2}\right)^{\left(\frac{-1}{\gamma-1}\right)\left(\frac{\gamma-1}{\gamma+1}\right)^{\frac{1}{2}}, P R_{T} \geq\left(\frac{\gamma+1}{2}\right)^{\left(\frac{\gamma}{\gamma-1}\right)}}
\end{gathered}
$$

The best fit value for the effective area is $C_{d} A=0.9$ in. $^{2}$. Also shown in figure 3 are the measured corrected rotor speeds for each measured flow rate. Equation (1) is a very good match to the measured values regardless of the speed. This typical turbine result is due to the fact that the flow rate is largely controlled by the fixed inlet nozzle throat area. Note that the choked (lower) form of equation (1) was not used in the calibration of figure 3. However, it was used in the Simulation section of the paper.

The orifice at the compressor discharge was next replaced with a calibrated flow meter in order to test compressor performance. Since the compressor was driven by the turbine, which in this setup was driven by cold air, little pressure rise was expected. Nevertheless, the test did supply measurable information which could be used to validate manufacturer supplied performance maps. The results of the test are shown in the map of figure 4 . The figure shows compressor pressure ratio as a function of corrected mass 


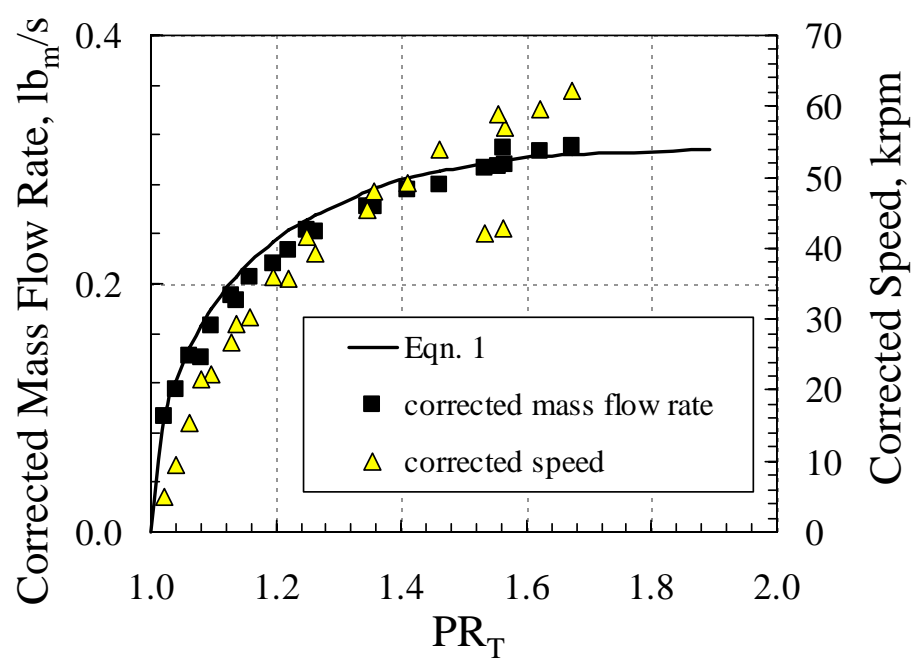

Figure 3.-Predicted and measured corrected mass flow rates through the turbocharger turbine as functions of turbine pressure ratio.

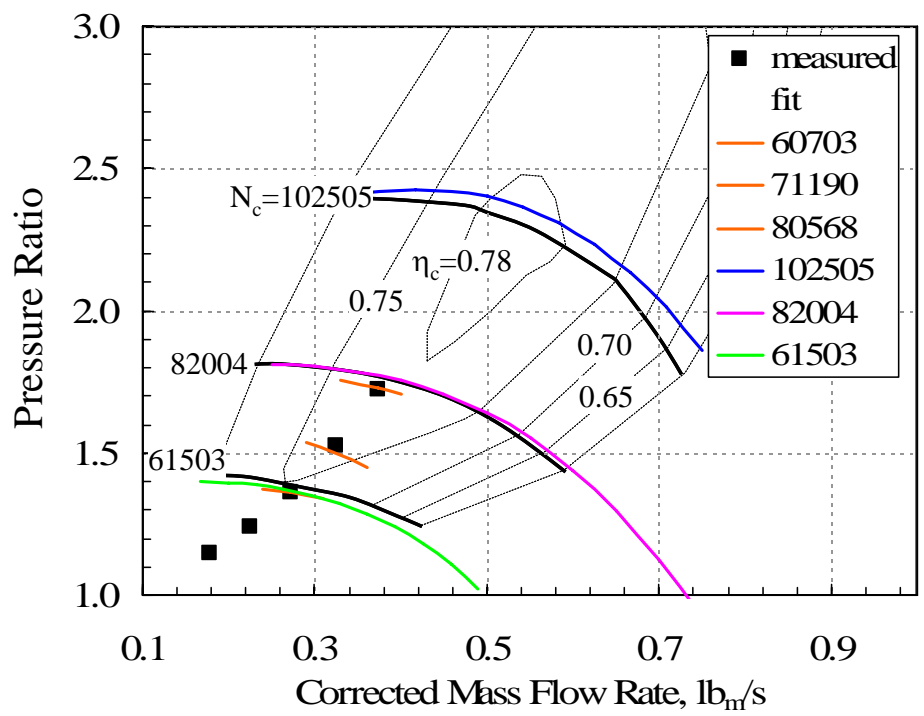

Figure 4.-Measured (symbols), manufacturer specified (black solid and dashed lines), and curve-fit (colored lines) compressor performance.

flow rate. The solid black lines represent lines of constant corrected speed supplied by the turbocharger manufacturer. The various colored lines represent an analytical, multi-variable curve fit to the manufacturer's data $\left(P R_{C}=f\left(N_{c}, w_{c}\right)\right.$. The fit is very good over the operating range of interest, and can be used to determine manufacturer specified performance on speed lines other than those shown on the map. The solid symbols indicate measured data points using the setup just described. The orange lines represent predicted performance at the measured rotor speed at flow rates near to, and including the measured values. It appears that the actual performance is very close to that specified by the manufacturer over the limited range of points measured. 


\section{Results}

After turbomachinery pre-testing the experiment was reassembled as shown in figure 1 . The system was then tested as per the sequence described above, and operational data was collected. It is worth noting at this point that there was no assurance that all of the components would work together as envisioned. Turbochargers are actually designed to operate with a much larger combustor pressure rise than could potentially be supplied by the one used in this experiment. Furthermore, it was pointed out in 2005 that the resonant combustion system of the current experiment may be very sensitive to boundary conditions. Thus, with a compressor fore and a turbine aft, it was not known if the device would operate at all. There was also significant uncertainty concerning resonant combustion at elevated temperature (from the compressor). It was mentioned in the introduction that the operational frequency would undoubtedly change. However, in a liquid fueled system it is often theorized that the vaporization rate of the fuel is critical in providing a combustion delay necessary for resonant operation. Vaporization rates are strongly affected by temperature. Such an issue might be resolved in the laboratory by varying the axial location of the fuel injection point to accommodate the reduced vaporization time. In the commercial unit used here however, no such adjustment was possible. All potential pitfalls considered then, it is encouraging that the system functioned at all, and even more so because it actually functioned quite well.

Figure 5 shows the measured output from all low frequency sensors over the course of one typical test run. The figure contains three plots. The first displays thrust, fuel flow rate, and rotor speed. The second

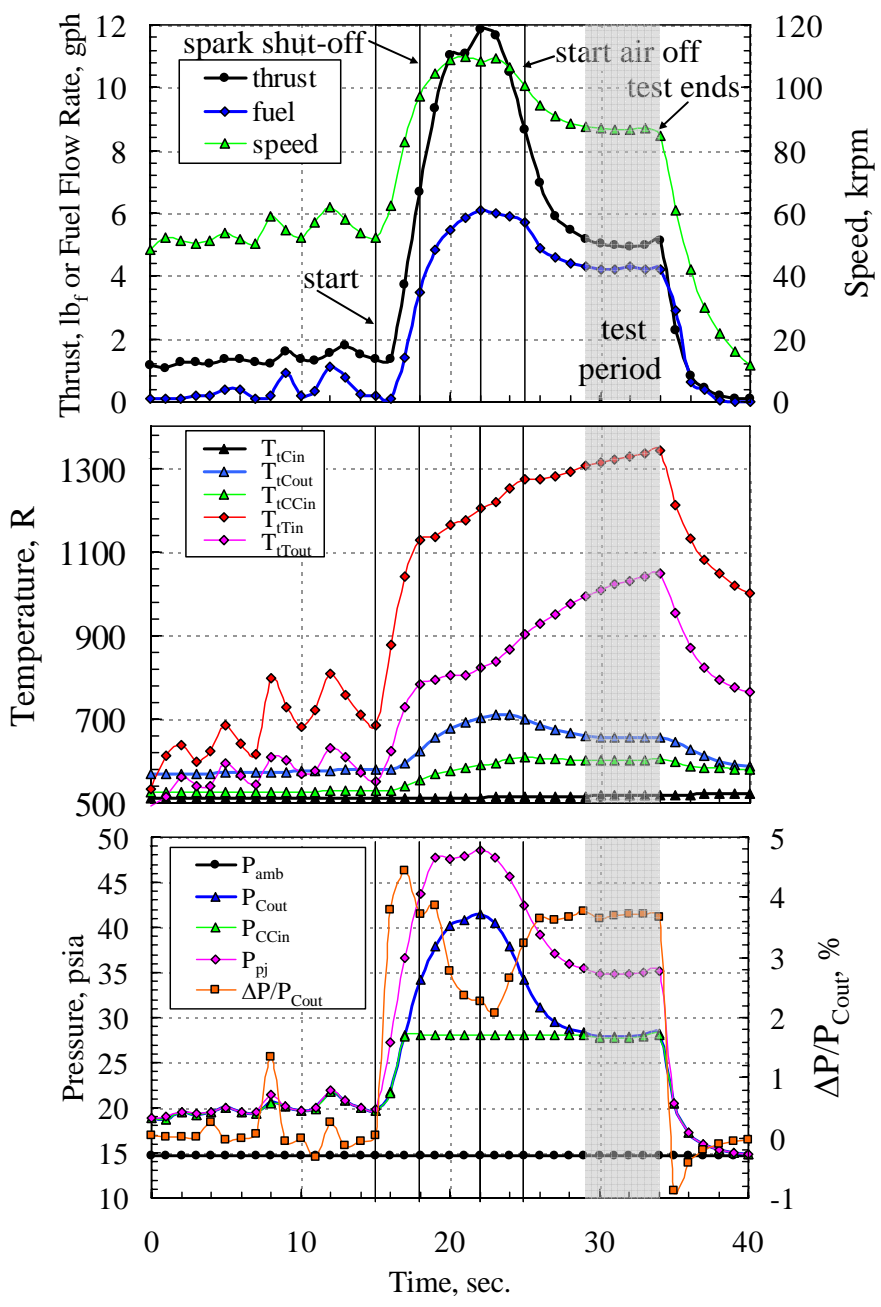

Figure 5.-Measured quantities as functions of time during a complete test run. 
displays temperatures. The third displays pressures and combustor pressure gain, with the latter being defined as $\Delta \mathrm{P} / \mathrm{P}_{\text {Cout }}$. The valid data collection period, that is, the time period during which the system is self-sustained, occurs between approximately 29 and 34 sec. This time span will heretofore be referred to as the test period. During the test period all measured values except temperature reached approximately steady state. The compressor discharge, and combustor inlet temperatures did reach near steady state values; however, it is clear that the turbine inlet and outlet values continued to climb until the end of the test period. The lack of thermal equilibrium is an unavoidable consequence of the limited test time, and the relatively large thermal mass of the rig. The combustor inlet pressure, $P_{C \text { Cin }}$ is correct over the test period; however, prior to that time the readings are invalid. When the transducer output exceeds the rated range by approximately 12 percent, the facility data acquisition system saturates and simply records a fixed reading. For this transducer, the value of that reading was 28.1 psia, which is very close to, but slightly above the test period readings.

\section{A. Discussion}

The data shown in figure 5 presents some results worthy of further exposition. First and foremost, the pressure gain combustion system performed almost identically with the surrounding turbomachinery as it did in the standalone configuration described in reference 2. The average combustor temperature ratio was 2.2, and the average pressure gain achieved was 3.70 percent. Given the combustor's reported sensitivity to boundary conditions, this result suggests that those imposed by the two experiments were similar. In the present experiment however, the inlet temperature to the combustor was approximately $80^{\circ} \mathrm{R}$ above the previous one. The resonant combustion process was apparently unaffected by the temperature change (though the operational frequency rose from 220 to $264 \mathrm{~Hz}$ ). As will be discussed in section IV, however, the inlet temperature rise had a profoundly negative effect on the longevity of the reed valves in the combustor pulsejet. Several modifications to the pulsejet were made in an effort to mitigate this effect. The changes involved the installation of a heat shield which was expected to yield reduced performance (i.e., less pressure-gain). Evidently, this was not the case.

Considering now the effect of unsteady combustion on component efficiencies, the average compressor adiabatic efficiency during the test period, defined as

$$
\eta_{C}=\frac{\left(P R_{C}^{\frac{(\gamma-1)}{\gamma}}-1\right)}{\left(\frac{T_{t \text { Cout }}}{T_{\text {tCin }}}-1\right)}
$$

was found to be $\eta_{C}=0.753$. For the measured speed, and pressure ratio, this is within 0.02 of the mapped steady flow value in figure 4 . The good agreement lent confidence to both the validity of the map, and the accuracy of the measurements. The slight discrepancy might be explained by the observation that both the compressor rotor and casing are heated by their close proximity to hot-section components. The result is a slight non-adiabatic heating of the compressed air which, if attributed to aerodynamic work in equation (2), results in reduced efficiency.

For the turbine, a quick glance at the average inlet and outlet temperatures during the test period indicates that the work done does not match that of the compressor. The measured temperature change across the turbine is considerably larger than that of the compressor. Of course, the two work rates must be the same, save for parasitic losses such as bearing friction and windage. The disparity is believed to be caused by the non-adiabatic nature of the turbine, and the lack of thermal equilibrium. The turbine wheel and casing are heating, and in doing so cause a cooling of the working fluid. Turbine adiabatic efficiencies calculated using the equation 


$$
\eta_{T}=\frac{\left(1-\frac{T_{\text {tTout }}}{T_{\text {tTin }}}\right)}{\left(1-P R_{T}^{\frac{(1-\gamma)}{\gamma}}\right)}
$$

yield values greater than 1.0 over the entire test period. If the actual turbine specific work is instead assumed to be the same as that of the compressor (bearing friction neglected), then the turbine efficiency becomes

$$
\eta_{T}=\frac{\left(T_{t \text { Cout }}-T_{t \text { Cin }}\right)}{T_{\text {tTin }}\left(1-P R_{T}^{\frac{(1-\gamma)}{\gamma}}\right)}
$$

The average turbine efficiency calculated using this formula was $\eta_{T}=0.65$ for the test period. Although no manufacturer quoted efficiency was available, the expected efficiency obtained from manufactures of other comparably sized turbochargers is approximately 0.68 to 0.70 (ref. 11). The approximately 7 percent disparity between the two is well within the margin of error caused by neglecting bearing friction and windage. Additionally, the use of $T_{\text {tTin }}$ in equation (4) is undoubtedly in error. Given the uninsulated length of pipe between the measurement point and the actual turbine entrance, along with the lack of thermal equilibrium, it is probable that the turbine entrance temperature used is too high. It therefore appears that the turbine efficiency does not suffer appreciably under the conditions of unsteadiness imposed by the pulsed combustor. It should be born in mind however that this result cannot be generalized to high efficiency aeropropulsion turbines. It is well known that as design point turbine efficiency drops, so does the sensitivity of the efficiency to perturbations in flow conditions. Nevertheless, the result is an encouraging one for the pressure-gain combustion concept.

Using the compressor map of figure 4 and the measured fuel flow rate, the average air to fuel ratio is $a / f=53.2$ over the test period. This corresponds to an average equivalence ratio of 0.282 . Using an available equilibrium chemistry reaction code (ref. 12) the expected turbine inlet temperature for a gasoline/air reaction at the measured equivalence ratio and combustor inlet conditions is $1915{ }^{\circ} \mathrm{R}$. Examination of the test period data of figure 4 shows that it is much lower than this at approximately $1324^{\circ} \mathrm{R}$. This substantial disparity cannot be attributed to a lack of thermal equilibrium. A more likely explanation is that rich combustion is occurring in the pulsejet at an equivalence ratio of approximately 1.4. The effluent then rapidly mixes with the bypass flow in the ejector and quenches to a temperature and equivalence ratio that effectively stops all further reaction (i.e., heat release). If the combustor inlet temperature were higher, the lean mixture downstream of the pulsejet may have completed its reaction since reaction rates are highly temperature dependant. This is the operating principle behind the rich-burn, quick-quench, lean-burn (RQL) combustor concept. Unfortunately, the compressor only heated the air to approximately $660^{\circ} \mathrm{R}$. Furthermore, the compressor discharge air was substantially cooled by the long duct leading to the combustor. The heating strip shown in figure 1 was meant to mitigate this problem, which it did to a large degree. Unfortunately, as discussed in section IV, and as mentioned earlier, elevating the combustor inlet temperature significantly reduced the operational life of the reed valves. In the end, the hoped for RQL type behavior of this combustor could not be demonstrated in this experimental configuration. Better valves and higher compressor discharge temperatures are required.

The average thrust measured during the test period was $5.05 \mathrm{lbf}$. Using this value, the turbine flow map of figure 3, the assumption of low exit Mach number, and the thrust equation, 


$$
F=\frac{\dot{m}_{T}^{2} R_{g} T_{\text {Tout }}}{A_{\text {eff }} p_{\text {Tout }} g_{C}}
$$

where the $A_{\text {eff }}$ is the effective exit area, equation (5) may be solved for $A_{\text {eff. }}$ The value obtained is $A_{\text {eff }}=$ $3.20 \mathrm{in}^{2}$. The measured area at the turbine exit is approximately $3.82 \mathrm{in}^{2}$. The 19 percent disparity between these values is likely tied to blockage caused by the rather thick blades of the turbine. An accurate measure of the blade thickness could not be made due to the inaccessibility of the turbine rotor; however, 20 percent blockage corresponds to a blade thickness of $0.1 \mathrm{in}$. which appears reasonable based on remote inspection. The relatively good match between measured and inferred exit areas lends confidence to the accuracy of the thrust measurements and the gas state measurements made upstream and downstream of the turbine.

\section{B. Noise Attenuation}

Pulsed combustors generate acoustically large pressure fluctuations. The fluctuations are often considered an objectionable aspect of the technology, regardless of their impact on turbine performance. It has been proposed however, that turbomachinery is very effective at attenuating these high levels of noise. Although the laboratory setup of this experiment was by no means constructed for acoustic measurements, the results which follow can at least provide an indication of that attenuation.

A high frequency pressure transducer is installed near the exit of the combustor, in the wall of the shroud. The location is shown in figure 1 near the station labeled " 3 ". The transducer output is ac coupled to a data acquisition device, and sampled at a rate of $10.0 \mathrm{kHz}$, over a $1.0 \mathrm{sec}$ interval, during the test period. A microphone is installed in the laboratory, approximately 98 in. from the turbine exit, at an angle of approximately $75^{\circ}$ to the turbine axis of symmetry. The microphone signal is amplified and coupled to the same data acquisition device as the upstream transducer. Co-located with the microphone is a handheld, calibrated, sound pressure level meter. The output display of the meter can be read from the control room during testing. Assuming the microphone response to be linear and flat over the frequency range of interest, the sound meter reading can be used to calibrate the voltage signal from the microphone with actual pressure fluctuations. Such a calibration was, in fact, performed during different stages of the full run shown in figure 5 and proved to be quite linear over a large amplitude range (i.e., rms microphone voltage was proportional to rms sound pressure level).

The results of these two sound pressure measurements are shown in figure 6 . The data are displayed in the form of rms amplitude spectra in $\mathrm{dB}^{1}$. The reference rms pressure is $2.9 \times 10^{-9} \mathrm{psia}$. Also shown in the figure are the rms sound pressure levels and weighted rms sound pressure levels described below. Examining first the shroud data, it is evident that there is significant acoustic energy beyond 2000, Hz. In fact, approximately $3 / 4$ of the measured energy lies in this region. This energy is believed to be related to the turbomachinery, not the pulsed combustion process. Similar shroud data taken from the 2005 testing without the turbocharger revealed virtually no content in this frequency range. As such, the weighted rms sound pressure is also presented in the plot. This can be thought of as the sound pressure level present if all of the energy above $2000 \mathrm{~Hz}$. were filtered from the signal. The weighted rms sound pressure level is $172 \mathrm{~dB}$. The full sound pressure level is $178 \mathrm{~dB}$. The majority of the combustion generated acoustic energy is concentrated in the fundamental, and first three harmonic modes of the pulsejet. The fundamental frequency is $264 \mathrm{~Hz}$. which is higher than the $224 \mathrm{~Hz}$. observed in the reference 2 experiment. This is due in part to the higher combustor inlet temperature of the present experiment, and also to the lower equivalence ratio at which the pulsejet is operating (closer to stoichiometric = higher temperature). It is interesting to note that the contribution to the acoustic energy is larger from the first

\footnotetext{
${ }^{1}$ The plotted data represent the rms amplitudes of the Fourier sine waves into which the original signal has been decomposed. It can be shown that the mean square of the original signal is equal to the sum of the mean square amplitude components.
} 


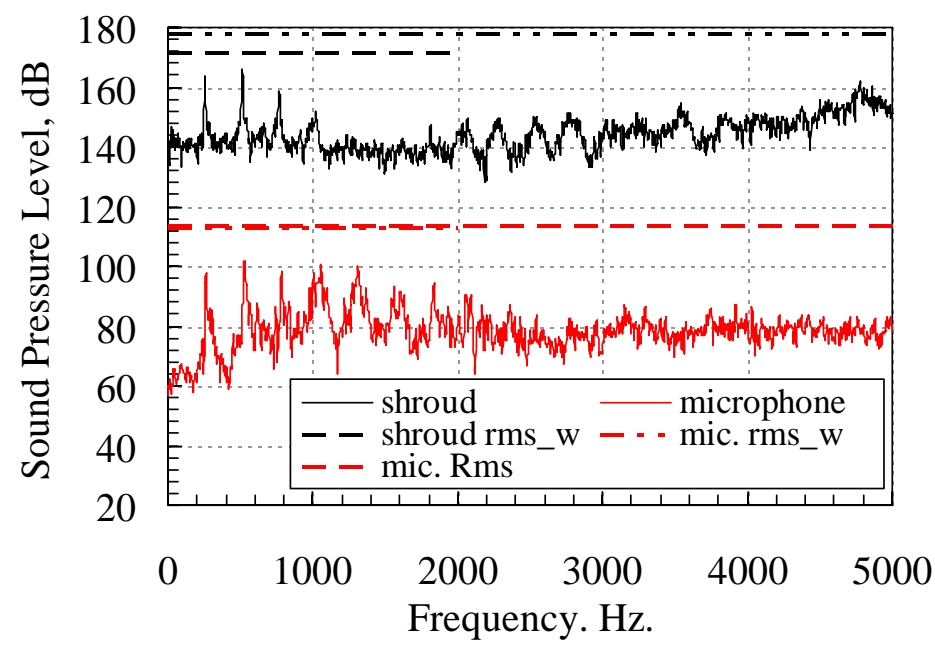

Figure 6.-Measured sound pressure levels upstream and downstream of the turbine as functions of frequency.

harmonic than from the fundamental mode. The reasons for this are not clear. It is noted, however, that although the processes occurring in the pulsejet combustion chamber are dominated by the fundamental mode, there are two gasdynamic events which traverse the tailpipe region for every one combustion event. In the tailpipe region therefore, the acoustic energy contribution from the first harmonic is relatively large. Since the majority of the shroud acoustic energy is assumed to come from the pulsejet tail pipe, it stands to reason that it too would show a rather large first harmonic (though not necessarily larger than the fundamental).

The amplitude spectrum from the microphone shows similar trends to that from the shroud; however, only 20 percent of the energy is contained in the signal beyond $2000 \mathrm{~Hz}$. Like the shroud data, the highest amplitude contributions come from the fundamental and first several harmonic frequencies associated with the pulsejet operation. The rms sound pressure level is $114 \mathrm{~dB}$, while the weighted value is $113 \mathrm{~dB}$. If it is assumed that most of the acoustic energy received by the microphone comes from the exhaust of the turbine, and if it is further assumed that the majority of this energy is radiated from the shroud through the turbine nozzle throat, then the sound pressure level one equivalent diameter (based on a throat area of $0.9 \mathrm{in.}^{2}$ ) downstream of the turbine exit may be estimated by scaling the microphone signal by the ratio of radial distances

$$
S P L_{\text {Tout }}=S P L_{\text {mic }}+20 \log \left(\frac{98.0}{1.07}\right)
$$

The value obtained from this estimate is $S P L_{\text {Tout }}=152 \mathrm{~dB}$. Comparing this to the weighted shroud sound pressure level of $172 \mathrm{~dB}$ indicates a turbine stage sound attenuation of approximately $20 \mathrm{~dB}$. This is consistent with attenuation measurements made with turbine stages coupled to detonative combustion systems (refs. 13 and 14).

\section{Operational Issues}

There were two related operational issues which affected the experiment strongly, and which could not be overcome in the time frame of the effort. The first, mentioned above, was the lack of thermal equilibrium in the rig. The only way to achieve this state is to increase the run time. The time required to reach equilibrium can be reduced somewhat through insulation, preheating components, and by using 


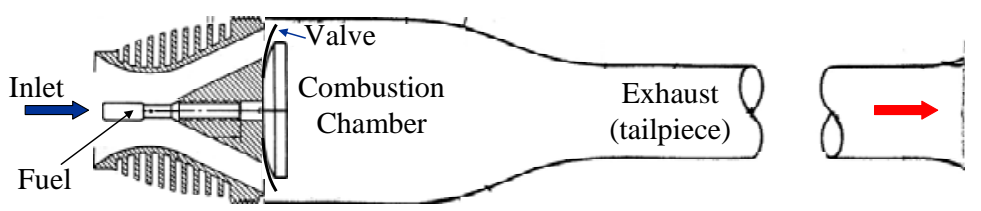

Figure 7.-Pulsejet reed-valve schematic.

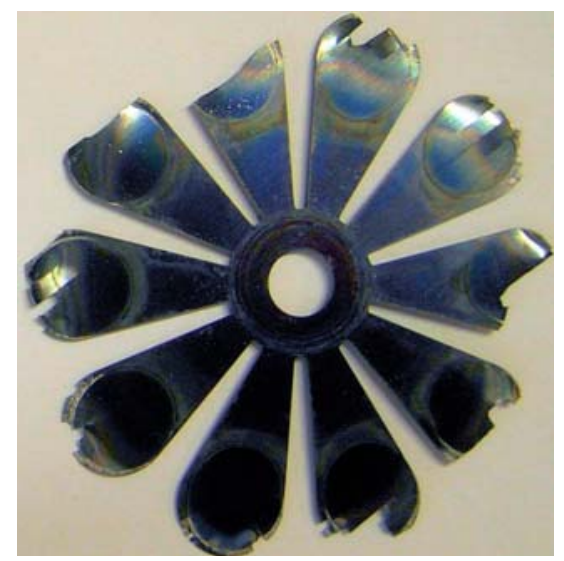

Figure 8.-Failed reed-valve.

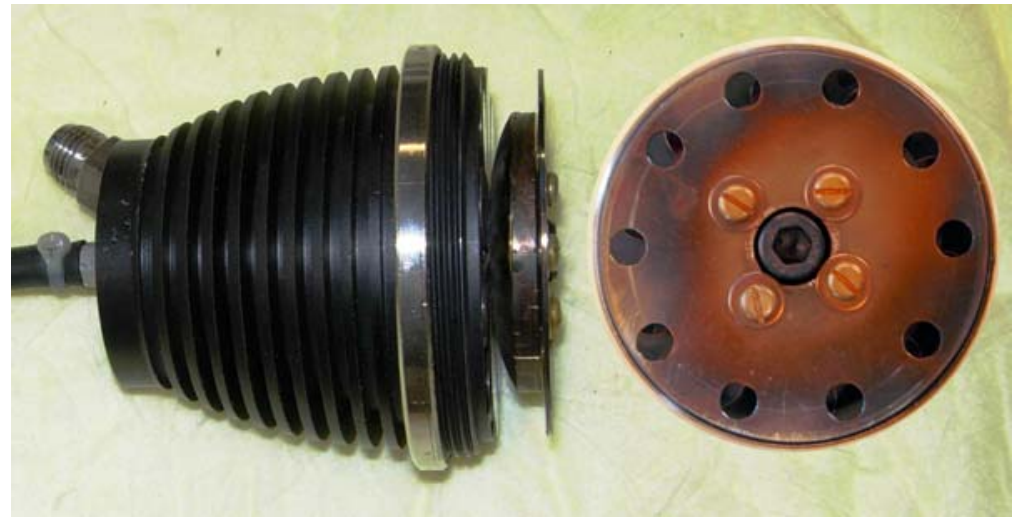

Figure 9.-Heat shield.

thinner gage material for ducting and housings. Longer run times are ultimately necessary however, and can only be achieved in this rig if the reed valves can be improved. An effective cooling scheme must also be devised for the body of the pulsejet which becomes red-hot during operation. For the latter issue, it is believed that a relatively simple fin-type system cooled by the bypass flow will help substantially. This potential solution remains an area for future work.

The second major operational issue of the experiment was the extremely short working life of the pulsejet reed valves. The reed valves are 0.006 in. thick spring steel "petals" that cover access ducts leading to the pulsejet combustion chamber from the inlet, as shown in figure 7. Under normal operating conditions, they undergo a punishing $220 \mathrm{~Hz}$. stress cycle during which they are drawn back and literally slammed closed in a thermal environment very close to the material limit. When operating in a pressuregain combustion configuration such as this experiment, conditions are far worse. The ambient pressure is elevated, as is the density of working fluid. This elevates both the mean pressure in the combustion chamber, and the pressure fluctuations associated with resonant combustion. This, in turn elevates the stresses on the reed valve as they are slammed ever harder. The temperature also rises, almost certainly exceeding material limits of steel. The result of this harsher environment was an initial inability to operate the system for more than a few seconds before the valves completely failed. An example of such a failure is shown in figure 8 . The discoloration and plastic deformation are symptomatic of high heat loads. Stacking two reed valves together increased run times to approximately $10 \mathrm{sec}$, however this was still not enough time to acquire meaningful data. As such, a heat shield was constructed and installed as shown in figure 9. The notional function of the shield is to absorb radiated and other transferred heat from the downstream combustion process while still allowing inflow through the holes and around the shield circumference into the combustion chamber. It was assumed that the shield would lead to reduced performance (through aerodynamic total pressure loss) but would protect the reed valves. The shield works quite well, and remarkably, yields almost no loss in performance. Test times are now in excess of 20 sec between failures, and failures are far less extreme when they occur. As mentioned earlier, the unit delivers the same pressure rise for a given temperature ratio as the 2005, reference 2 tests in which no heat shield was installed.

High temperature Inconel reed valves were also tested in an effort to achieve multiple test runs per valve change. Unfortunately, they are thicker ${ }^{2}$ (0.007 in.) than the steel valves, and have slightly

\footnotetext{
${ }^{2}$ Inconel spring material was not available in sheets of 0.006 in. thickness from identified suppliers.
} 
different strength properties. The result is that they do indeed last longer, but the performance of the pulsejet, and thus the combustor, is poorer. For this reason, they are not used in the experiment.

Reed valves have always been a problematic aspect of pulsejets. They don't last long under the best of circumstances, but without them, in the so-called aerovalved pulsejet designs, performance usually suffers. That being said, it should be noted that no known effort has ever been undertaken to improve reed valve design since the 1950s. It is an area that, if explored with up to date knowledge of material properties, and modern analysis techniques, might yield radical improvements. Alternatively, it may be possible to develop active, closed loop valve systems which operate in a manner that does not generate the fantastic stresses seen in reed valves. This too is an area ripe for exploration.

\section{Simulation}

In order to experimentally investigate the impact of pressure gain combustion on engine performance, a complete study would have included the installation of a conventional (pressure-loss) combustor run at the same temperature ratio. This was not possible with the resources available. Instead, a simulation was developed as an alternate investigative tool. Transient, or dynamic behavior was not the focus of the simulation, and as such, a cycle deck approach could have been used (ref. 15). However, dynamic simulations can often march in time to a steady solution as fast as a cycle deck can iterate to one. Furthermore, for single stage component systems such as the turbocharger, there is less effort expended in coding the equations of motion than there is in configuring a cycle deck. For these reasons, the dynamic simulation approach was chosen. Four state equations are required, governing compressor mass flow rate, combustor pressure and density, and rotor speed. These equations, combined with the component maps used for figures 3 and 4, the perfect gas equation of state, an imposed combustor pressure gain (or loss), and an assumed fuel heating value, provide a complete simulation. The form of the equations is straightforward, and may be found in the literature (ref. 16). The simulation is implemented on a spreadsheet using a simple two-step, Runge-Kutta integration scheme. Components are modeled as purely adiabatic. Figure 10 shows the simulated results of a typical test run, including startup. The results should be compared to figure 5 . The fuel flow is scheduled in the simulation since the combustor cannot yet be modeled. The scheduled fuel flow rate is chosen such that the turbine inlet temperature matches the experimentally measured value during the test period. It can be seen that many aspects of the simulation match the measured data very well. In particular, the pressures, temperatures, rotor speed and thrust match closely during the test period.

With some confidence then that the simulation correctly predicts steady state operation, the results of a new simulation are shown in figure 11 . Starting at the steady state condition corresponding to the figure 10 test period, the prescribed 3.5 percent combustor pressure rise is abruptly changed to a 1.0 percent loss. The simulation response is shown in the first $5.0 \mathrm{sec}$ of the figure. The speed and thrust drop immediately, and the turbine inlet temperature rises. In an effort to make an appropriate comparison with the pressure gain system, the fuel flow rate is next reduced so that the turbine inlet temperature would rise. The system response is shown in the period from 5 to 10 sec. Again the speed and thrust drop, and the turbine inlet temperature rises. The turbine inlet temperature rise occurs because the air mass flow through the system drops proportionally more than the fuel flow. On a per pound basis then, there is actually more fuel present which yields higher combustor exit temperatures. Further reductions in fuel flow, shown partially from 10 to $15 \mathrm{sec}$ in figure 11 result in a spiraling sequence of speed (and mass flow) reductions and turbine temperature rises until the simulated system no longer operates. The conclusion to be drawn from these results is that, without a pressure gain combustor, the turbocharger cannot operate at the experimentally measured turbine inlet temperature of approximately $1320^{\circ} \mathrm{R}$. Thus, it is further concluded, the addition of a pressure gain combustion system (neglecting the poor fuel utilization exhibited by this particular pulsejet) quite dramatically improves the performance of this particular gas turbine system. 


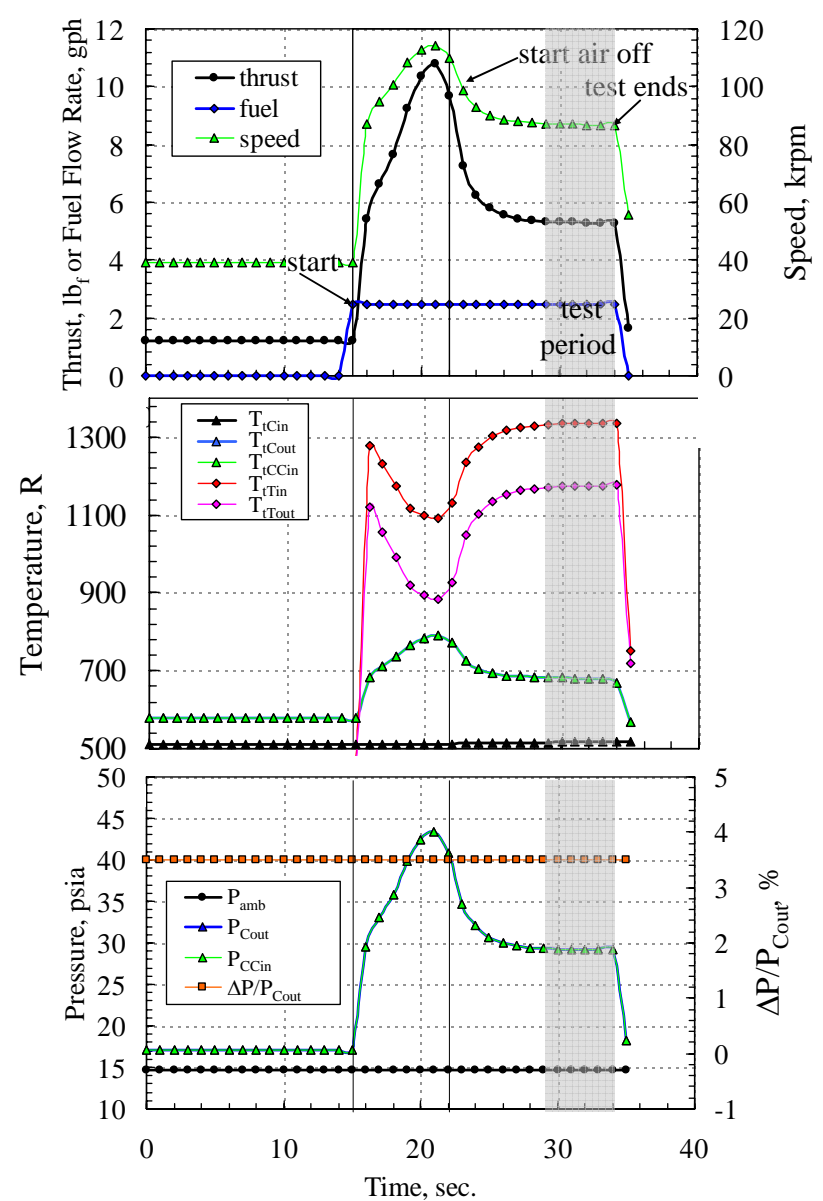

Figure 10.-Simulated system quantities as functions of time during a complete test run.

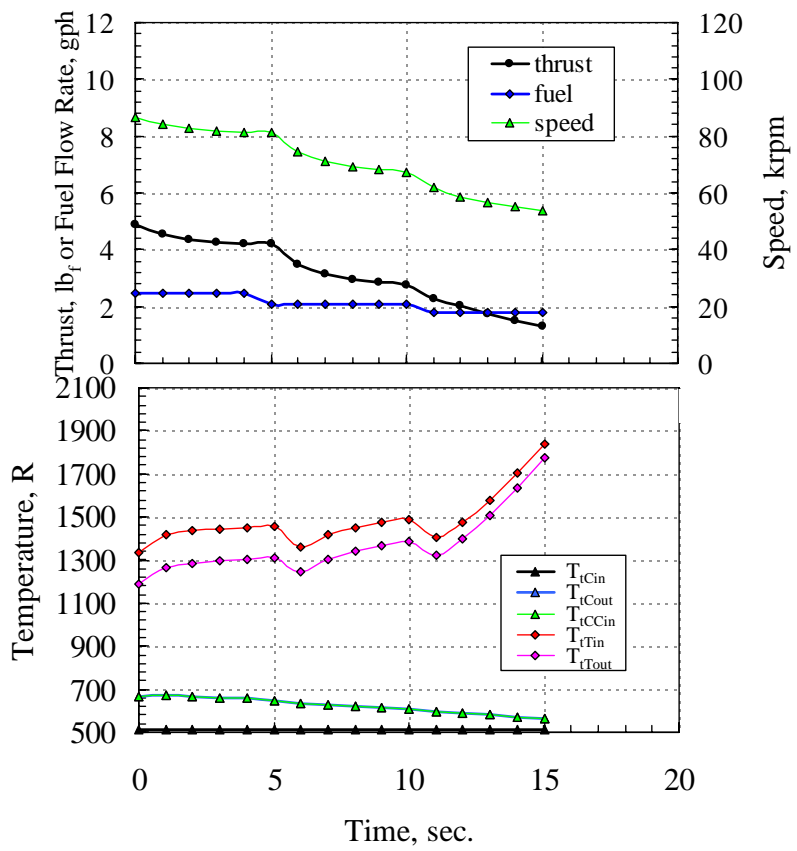

Figure 11.--Simulated system quantities as functions of time with a conventional 1 percent pressure loss combustor in place. 


\section{Summary and Conclusion}

Operability of a small scale, pressure-gain combustor topped gas turbine engine was experimentally investigated. Installed instrumentation allowed for component performance assessment in the presence of pressure fluctuations associated with unsteady, pressure-gain combustion. The combustor performed well, yielding a pressure gain of approximately 3.7 percent while generating a temperature ratio of 2.2. The turbomachinery components, as measured by efficiency calculations, performed approximately the same as during steady operation. The entire system ran stably and in a repeatable manner for a test period of $5 \mathrm{sec}$, generating $5.0 \mathrm{lbf}$ thrust at a turbine inlet temperature of $1320^{\circ} \mathrm{R}$. Validated simulation of the turbocharger indicated that without the pressure gain combustor present, the turbocharger could not operate at the measured turbine inlet temperature. Sound surveys showed a turbine induced attenuation of combustor noise of approximately $20 \mathrm{~dB}$, consistent with other published literature. Technical issues associated with implementing the experiment were presented and discussed. Chief among these is shortlived reed valves in the pulse combustor. This technological challenge is critical for the advancement of pressure gain combustion.

\section{References}

1. Lefebvre, Arthur, H., Gas Turbine Combustion, Taylor and Francis, 1999, Chapt. 4.

2. Paxson, D.E., and Dougherty, K.T. "Ejector Enhanced Pulsejet Based Pressure-Gain Combustors: An Old Idea With A New Twist,” AIAA Paper 2005-4216, 2005.

3. Catchpole, B.G., and Runacres, A., "Constant Volume Gas Turbine Experiments with Gaseous Fuel in a Rotating Pocket Combustor," Mechanical Engineering Note 353, Australian Defense Scientific Service Aeronautical Research Laboratories, October, 1974.

4. Mathur, Atul, “A Breif Review of the G.E. Wave Engine Program,” Proceedings of the 1985 ONR/NAVAIR Wave Rotor Research and Technology Workshop, May, 1985.

5. Kentfield, J.A.C., and O’Blenes, M.J., "Small Gas Turbine Using a Second-Generation Pulse Combustor,” AIAA Journal of Propulsion, vol. 6 no. 2, 1990, pp. 214-220.

6. Gemmen, R.S., et al., “Achieving Improved Cycle Efficiency Via Pressure Gain Combustors,” ASME 95-GT-63, June, 1995.

7. Snyder, P.H., Alparslan, B., Nalim, M.R., "Gas Dynamic Analysis Of The CVC, A Novel Detonation Cycle,” AIAA paper 2002-4069, July, 2002.

8. Paxson, D.E., Perkins, H.D.,“Thermal Load Considerations for Detonative Combustion-Based Gas Turbine Engines,” AIAA-2004-3396, July, 2004.

9. Paxson, D.E., Dougherty, K.T., “Unsteady Ejector Performance: An Experimental Investigation Using a Pulsejet Driver,” AIAA-2002-3915, July, 2002.

10. White, Frank, M., Fluid Mechanics, McGraw-Hill, New York, 1979, pp. 356.

11. Garrett Products Turbocharger Information Website, http://www.turbobygarrett.com/turbobygarrett/ catelog/Turbochargers/GT37/GT3782_452159_3.htm, 2007.

12. Gordon, S. and McBride, B.J., "Computer Program for Calculation of Complex Chemical Equilibrium Compositions and Applications,” NASA RP 1311, October 1994.

13. Rahseed, A., Furman, A., Dean, A., "Wave Attenuation and Interactions in a Pulsed Detonation Combustor-Turbine Hybrid System,” AIAA paper 2006-1235, January, 2006.

14. Caldwell, N., Glaser, A., Gutmark, E., "Acoustic Interactions of a Pulse Detonation Engine Array with a Gas Turbine,” AIAA paper 2006-1233, January, 2006.

15. Plencner, R., and Snyder, C., “The Navy/NASA Engine Program,” NASA TM-105186, 1991.

16. Seldner, K., Mihaloew, J, and Blaha, R., "Generalized Simulation Technique for Turbojet Engine System Analysis,” NASA TN-D-6610, 1972. 



\section{Appendix}

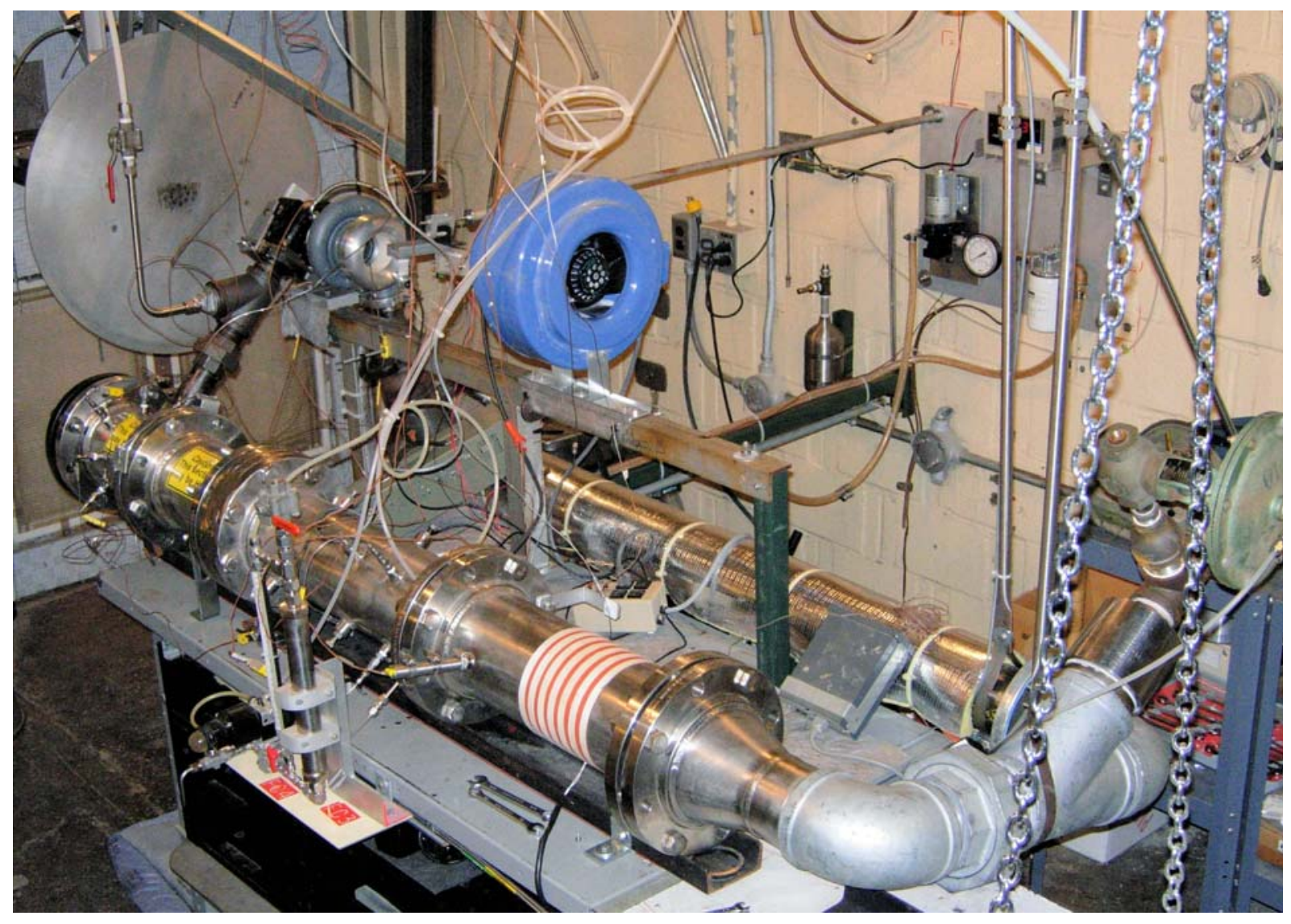

Figure 12.-Photograph of the pressure-gain, gas turbine rig. 


\begin{tabular}{|c|c|c|}
\hline \multicolumn{2}{|c|}{ REPORT DOCUMENTATION PAGE } & $\begin{array}{l}\text { Form Approved } \\
\text { OMB No. 0704-0188 }\end{array}$ \\
\hline \multicolumn{3}{|c|}{ 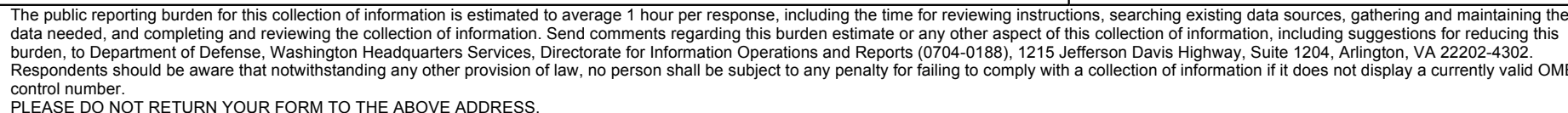 } \\
\hline $\begin{array}{l}\text { 1. REPORT DATE (DD-MM-YYYY) } \\
01-03-2008\end{array}$ & $\begin{array}{l}\text { 2. REPORT TYPE } \\
\text { Technical Memorandum }\end{array}$ & 3. DATES COVERED (From - To) \\
\hline \multirow{3}{*}{\multicolumn{2}{|c|}{$\begin{array}{l}\text { 4. TITLE AND SUBTITLE } \\
\text { Operability of an Ejector Enhanced Pulse Combustor in a Gas Turbine Environment }\end{array}$}} & 5a. CONTRACT NUMBER \\
\hline & & 5b. GRANT NUMBER \\
\hline & & 5c. PROGRAM ELEMENT NUMBER \\
\hline \multirow{3}{*}{\multicolumn{2}{|c|}{$\begin{array}{l}\text { 6. AUTHOR(S) } \\
\text { Paxson, Daniel, E.; Dougherty, Kevin }\end{array}$}} & 5d. PROJECT NUMBER \\
\hline & & 5e. TASK NUMBER \\
\hline & & $\begin{array}{l}\text { 5f. WORK UNIT NUMBER } \\
\text { WBS 561581.02.08.03.17.02 }\end{array}$ \\
\hline \multicolumn{2}{|c|}{$\begin{array}{l}\text { 7. PERFORMING ORGANIZATION NAME(S) AND ADDRESS(ES) } \\
\text { National Aeronautics and Space Administration } \\
\text { John H. Glenn Research Center at Lewis Field } \\
\text { Cleveland, Ohio 44135-3191 }\end{array}$} & $\begin{array}{l}\text { 8. PERFORMING ORGANIZATION } \\
\text { REPORT NUMBER } \\
\text { E-16410 }\end{array}$ \\
\hline \multirow{2}{*}{\multicolumn{2}{|c|}{$\begin{array}{l}\text { 9. SPONSORING/MONITORING AGENCY NAME(S) AND ADDRESS(ES) } \\
\text { National Aeronautics and Space Administration } \\
\text { Washington, DC 20546-0001 }\end{array}$}} & $\begin{array}{l}\text { 10. SPONSORING/MONITORS } \\
\text { ACRONYM(S) } \\
\text { NASA }\end{array}$ \\
\hline & & $\begin{array}{l}\text { 11. SPONSORING/MONITORING } \\
\text { REPORT NUMBER } \\
\text { NASA/TM-2008-215169; AIAA-2008- } \\
0119\end{array}$ \\
\hline \multicolumn{3}{|c|}{$\begin{array}{l}\text { 12. DISTRIBUTION/AVAILABILITY STATEMENT } \\
\text { Unclassified-Unlimited } \\
\text { Subject Category: } 07 \\
\text { Available electronically at http://gltrs.grc.nasa.gov } \\
\text { This publication is available from the NASA Center for AeroSpace Information, 301-621-0390 }\end{array}$} \\
\hline
\end{tabular}

\section{SUPPLEMENTARY NOTES}

\section{ABSTRACT}

A pressure-gain combustor comprised of a mechanically valved, liquid fueled pulsejet, an ejector, and an enclosing shroud, was coupled to a small automotive turbocharger to form a self-aspirating, thrust producing gas turbine engine. The system was constructed in order to investigate issues associated with the interaction of pulsed combustion devices and turbomachinery. Installed instrumentation allowed for sensing of distributed low frequency pressure and temperature, high frequency pressure in the shroud, fuel flow rate, rotational speed, thrust, and laboratory noise. The engine ran successfully and reliably, achieving a sustained thrust of 5 to $6 \mathrm{lbf}$, and maintaining a rotor speed of approximately $90,000 \mathrm{rpm}$, with a combustor pressure gain of approximately 4 percent. Numerical simulations of the system without pressure-gain combustion indicated that the turbocharger would not operate. Thus, the new combustor represented a substantial improvement in system performance. Acoustic measurements in the shroud and laboratory indicated turbine stage sound pressure level attenuation of $20 \mathrm{~dB}$. This is consistent with published results from detonative combustion experiments. As expected, the mechanical reed valves suffered considerable damage under the higher pressure and thermal loading characteristics of this system. This result underscores the need for development of more robust valve systems for this application. The efficiency of the turbomachinery components did not appear to be significantly affected by unsteadiness associated with pulsed combustion, though the steady component efficiencies were already low, and thus not expected to be particularly sensitive.

\section{SUBJECT TERMS}

Combustor; Gas turbine engine; Pulsejet engines

\begin{tabular}{|c|c|c|c|c|c|}
\hline \multicolumn{3}{|c|}{ 16. SECURITY CLASSIFICATION OF: } & \multirow{2}{*}{$\begin{array}{l}\text { 17. LIMITATION OF } \\
\text { ABSTRACT } \\
\text { UU }\end{array}$} & \multirow{2}{*}{$\begin{array}{l}\text { 18. NUMBER } \\
\text { OF } \\
\text { PAGES } \\
22\end{array}$} & \multirow{2}{*}{$\begin{array}{l}\text { 19a. NAME OF RESPONSIBLE PERSON } \\
\text { STI Help Desk (email:help@ } \text { sti.nasa.gov) } \\
\text { 19b. TELEPHONE NUMBER (include area code) } \\
\text { 301-621-0390 }\end{array}$} \\
\hline $\begin{array}{l}\text { a. REPORT } \\
\text { U }\end{array}$ & $\begin{array}{l}\text { b. ABSTRACT } \\
U\end{array}$ & $\begin{array}{l}\text { c. THIS } \\
\text { PAGE } \\
U\end{array}$ & & & \\
\hline
\end{tabular}



